\title{
Evaluation on Bali Mynah (Leucopsar rothschildi Stresemann, 1912) population, result of release process 1998-2015 in Bali Barat National Park, Indonesia
}

\author{
JARWADI BUDI HERNOWO ${ }^{1, \boldsymbol{v}}$, SHINDY HAQUESTA ${ }^{2}$ \\ ${ }^{1}$ Wildlife Ecology Laboratory, Department of Forest Resources Conservation and Ecotourism, Faculty of Forestry and Environment, Institut Pertanian Bogor. \\ Jl. Ulin Lingkar Akademik, Kampus IPB Dramaga, Bogor 16680, West Java, Indonesia. Tel.: +62-251-8621677, Fax.: +62-251-8621256, ”email: jblina11@ gmail.com \\ ${ }^{2}$ Department of Forest Resources Conservation and Ecotourism, Faculty of Forestry and Environment, Institut Pertanian Bogor. J1. Ulin Lingkar \\ Akademik, Kampus IPB Dramaga, Bogor 16680, West Java, Indonesia
}

Manuscript received: 11 March 2021. Revision accepted: 14 June 2021.

\begin{abstract}
Hernowo JB, Haquesta S. 2021. Evaluation on Bali Mynah (Leucopsar rothschildi Stresemann, 1912) population, result of release process 1998-2015 in Bali Barat National Park, Indonesia. Biodiversitas 22: 2699-2710. The release of Bali Mynah (Leucopsar rothschildi Stresemann, 1912) is an attempt to return the bird population to its natural habitat to increase the number of Bali Mynah populations in nature. Bali Mynah population release results that can grow, but slow rate, so that indicates to review technical and management evaluation of Bali Mynah release. The study aims to evaluate the development of the population, the factors that affect population numbers and habitat for the results of releasing Bali Mynah, as well as the security factor. The research was conducted and focused on the Breeding Centre of Bali Mynah (BCBM) in Tegal Bunder, Teluk Brumbun, Teluk Kotal, Tanjung Gelap, and Pos Lampu Merah of Bali Barat National Park (BBNP), Indonesia from May to June 2015. The method of data collection is direct observation, measurement (population with concentration method), interview in relation to management of the bird, and literature. Data analysis was done by calculating the score of the assessment and the animal welfare. The result shows that the Bali Mynah population in Breeding Centre of Bali Mynah in Tegal Bunder has been categorized as good (analyzed from the animal welfare and assessment of the Bali Mynah with a score of 76.53 and 4.32 respectively). Bali Mynah population in the release area is well developed. The BM population has shown survival supported by an abundance of food and water availability, but the movement is still limited (500 m-1000 m) from the release areas.
\end{abstract}

Keywords: Evaluation, Bali Mynah, population, release

\section{INTRODUCTION}

The Bali Mynah (Leucopsar rothschildi Stresemann, 1912) population is declining rapidly due to illegal hunting, lack of security and surveillance, lack of legal sanctions, and low public awareness. Nowadays, the population of this wild bird (nature bird/not from release) is in a very alarming situation, which will likely lead to extinction of the population is not adequately managed (Hernowo 2017). Illegal trapping for the wildlife trade is the primary threat to the survival of the Bali Starling in the wild (Jepson 2016). Bali Mynah is in the red list category and is in the Critically Endangered criteria (Birdlife International 2018). According to CITES (2019), the Bali Mynah is listed in Appendix I of CITES.

To improve Bali Mynah population, the Indonesian government has a policy to release Bali Mynah to nature. The release effort was done by the Ministry of Forestry together with BirdLife Indonesia Programme and Bali Mynah Breeder Association (APCB) in 2007 in Bali Barat national park. Conservation effort of Bali Mynah has been planned through Bali Barat National Park long term planning which is done continuously by improving the natural population through release resulting from the breeding program (BBNP 2013). According to BBNP (2012), around 218 Bali starling birds have been released to nature from 1998 to 2012.

The release of Bali Mynah has been done with the main objective to return Bali Mynah population to its natural habitat and to increase the population. The center of Bali Mynah release has been focused on several places such as Teluk Brumbun, Teluk Kotal, Tanjung Gelap, Cekik and Pos Lampu Merah in Bali Barat National Park (BBNP), Indonesia. There has not been any explanation or evaluation regarding the Bali Mynah release from 1992 up to now. The success and the failures and how to handle the handicap are in every stage of release (Pre-release, Release and Post-Release). In general, evaluation of Bali Mynah release is in relation to the techniques, social problems, and the management that hasn't been conducted properly. The result on evaluation of Bali Mynah (BM) population from the release process hopefully can prevent the mistakes on release process and suggest improvement that should be done from management authority until field problems can be handled.

The goal of this manuscript is: (i) To evaluate the Bali Mynah population in breeding center of Bali Mynah at Tegal Bunder BBNP, (ii) To evaluate the release process of Bali Mynah population (pre-release, release, and postrelease) in Teluk Brumbun, Teluk Kotal, Tanjung Gelap and Pos Lampu Merah BBNP, (iii) To evaluate development of Bali Mynah which was released from 1998 
to 2015 in BBNP, (iv) To evaluate safety factor and management of the release process of Bali Mynah.

\section{MATERIALS AND METHODS}

\section{Data collection}

Field observation was done from April to June 2015, and sample locations were Teluk Brumbun, Teluk Kotal, Tanjung Gelap, Pos Lampu Merah of Bali Barat National Park (BBNP), Indonesia. Primary data (pre-release), such as information of Breeding Centre of Bali Mynah (BCBM), were collected in Tegal Bunder of BBNP in relation to breeding management of the bird, cages, food, health, and individual selection for release, pre-release, release, postrelease (Table 1$)$.

\section{Interview}

The interview was done on key informants who knew the condition of release management of Bali Mynah (BM). The key informants were head resort of BBNP, forest researcher, forest policeman, and village people who knew about BM release.

\section{Document assessment}

Document assessment was done to get data on breeding and $\mathrm{BM}$ release management. The data come from the grand design of $\mathrm{BM}$ release and $\mathrm{BM}$ inventory report, honor thesis, journals, and websites related to BM breeding and release.

\section{Field observation}

Field observations were done to collect data of release management, monitoring, and evaluation of the BM population released. The method to observe released BM population was concentration count. The data were collected for population including individual number, number of pair, number of adult bird, number of juveniles. BM monitoring covers population, habitat, and activities done by BM. Point concentrations of BM were set as points for counting the birds. Observation was done every day in the morning (06.00-08.00 AM) and evening (16.00-18.00 PM). The BM counting was done in 30 days. The BM activities were observed in roosting site, feeding site, and nest boxes.

\section{Data analysis}

\section{Bird management analysis}

Achievements of bird management criteria were done by fill-in of bird management evaluation table, by providing values on the specified variable. The variable values are as follows: very good $=5, \operatorname{good}=4$, enough $=3$, $\operatorname{bad}=2$, very bad $=1$. The result of management value was counted using the formula below and was evaluated and classified according to Table 2.

$$
\begin{gathered}
\text { Achievement of Implementation management }= \\
\qquad \frac{\sum X}{\text { Management Aspect }}
\end{gathered}
$$$$
\mathrm{X}=\text { Average value of management aspect }
$$

Note: Included Management Aspect covers: administration and management aspect, food and water aspect, management of the cage, bird health, and human resources.

The rating classification of bird management is as follows in Table 2.

\section{Bird welfare analysis}

Bird welfare was derived from achieved bird welfare criteria done by charging table welfare factor on every variable. Classification of bird welfare assessment was done by weight value. The scores of every variable are listed in the regulation of the Directorate General of Forest Protection and Nature Conservation No.6 (2011). Assessment Guidelines for Conservation Entities are: very $\operatorname{good}=5, \operatorname{good}=4$, enough $=3, \operatorname{bad}=2$, very $\operatorname{bad}=1$. The value of every variable on welfare aspect is added up, and the average value is counted. To get a weight value the following formula was used.

$$
\begin{aligned}
& \text { Weight value }=\text { Weight } \times \text { Score } \\
& \text { Assessment score }=\frac{\sum \text { waight va[u }}{\mathbf{5}}
\end{aligned}
$$

Determination of weight for the five components of bird welfare can be seen in Table 3 .

The results from the formula will be value for bird welfare which refers to regulation of the Directorate General of Forest Protection and Nature Conservation No. 6 (2011). Assessment Guidelines of Conservation Entities can be seen in Table 4.

\section{RESULTS AND DISCUSSION}

\section{General condition of study site}

Bali Mynah can be found in monsoon forests, savannas, mangroves, and beech forests in Bali Barat national park. The locations of BM release are in Teluk Brumbun, Pos Lampu Merah, Teluk Kotal and Tanjung Gelap. The vegetation used by BM at the release locations is fruit of intaran (Azadirachta indica), caterpillar or insect at pilang (Acacia leucophloea), talok (Grewia koordersiana), and walikukun (Shoutenia ovata). Besides for searching food, the trees are used for resting and roosting site of BM. According to Sudaryanto et al. (2015), trees that the Bali Starling widely uses to roost and sleep in Bali Barat National Park consist of White-bark acacia (Acacia leucophloea) (48.1\%) and East Indian wood (Schoutenia ovata) (17\%). Other trees, such as berry (Grewia koordersiana), Lebbeck tree (Albizia lebbeck), Indian gooseberry (Phyllanthus emblica), Ceylon oak (Schleichera oleosa), and Indian lilac (Azadirachta indica) are also used by this type of bird. In addition to perching, this bird also obtain caterpillars, ants, and termites for feeding. 
Table 1. Data collected and methods

\begin{tabular}{|c|c|c|}
\hline Object & Variable & Methods \\
\hline \multicolumn{3}{|l|}{ Breeding } \\
\hline Cage & $\begin{array}{l}\text { gender, individual number, individual number/cage, cage type, } \\
\text { material, cage size, availability of feeding site, drinking site, } \\
\text { nesting site, resting site and cage management }\end{array}$ & $\begin{array}{l}\text { Field observation, interview, } \\
\text { and document assessment }\end{array}$ \\
\hline Food and water & $\begin{array}{l}\text { kind of food, number, time for feeding, feeding technique and } \\
\text { feeding frequencies }\end{array}$ & \\
\hline Health & $\begin{array}{l}\text { Health condition, frequencies of checking, control and prevention, } \\
\text { availability of medicine, medical record }\end{array}$ & \\
\hline Individual selecting for release & $\begin{array}{l}\text { age, gender, bird ringing mark, individual number, origin of } \\
\text { individual }\end{array}$ & \\
\hline \multicolumn{3}{|l|}{ Pre-release } \\
\hline Preparation & $\begin{array}{l}\text { bird selection, gender selection, perform subpopulation, medical } \\
\text { record, training before release, ringing, feeding and drinking site, } \\
\text { nesting site (nest box), making big cage }\end{array}$ & $\begin{array}{l}\text { Interview and document } \\
\text { assessment }\end{array}$ \\
\hline Cage & $\begin{array}{l}\text { gender, individual number, individual number/cage, cage type, } \\
\text { material, cage size, availability of feeding site, drinking site, } \\
\text { nesting site, resting site and cage management }\end{array}$ & \\
\hline Food and water & $\begin{array}{l}\text { kind of food, number, time of feeding, feeding technique and } \\
\text { feeding frequencies }\end{array}$ & \\
\hline \multicolumn{3}{|c|}{ 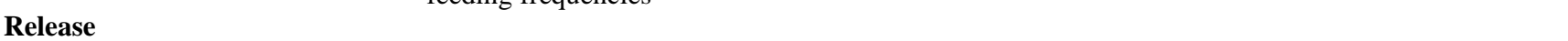 } \\
\hline Evaluation of release & $\begin{array}{l}\text { Administration record, site of release, release technique, food } \\
\text { ration around big cage, monitoring to the bird }\end{array}$ & $\begin{array}{l}\text { Field observation, interview, } \\
\text { and document assessment }\end{array}$ \\
\hline \multicolumn{3}{|l|}{ Post-release } \\
\hline Population in wild & Individual number, age, gender, movement, productivity & Field observation, interview, \\
\hline Habituation and adaptation & $\begin{array}{l}\text { Habitat use (feeding site, resting site, roosting site, nesting site, } \\
\text { cover) adaptation, bird activities during monitoring }\end{array}$ & and document assessment \\
\hline Disturbance & Predator, competitor, people disturbance & \\
\hline
\end{tabular}

Table 2. Rating classification of bird management

\begin{tabular}{ll}
\hline Rating classification & Score \\
\hline Very good & $\geq 5$ \\
Good & $4-4.9$ \\
Moderate & $3-3.9$ \\
Bad & $2-2.9$ \\
Very bad & $1-1.9$ \\
\hline
\end{tabular}

Table 3. The weighting parameters of bird welfare

\begin{tabular}{lccc}
\hline Component & Weight & $\begin{array}{c}\text { Scoring } \\
\text { (average) }\end{array}$ & $\begin{array}{c}\text { Weight } \\
\text { value }\end{array}$ \\
\hline Free from hunger and thirst & 30 & $(1$ until 5) & $\mathrm{A}=\mathrm{B} \times \mathrm{C}$ \\
Free from pain, disease, injury & 20 & $(1$ until 5) & $\mathrm{A}=\mathrm{B} \times \mathrm{C}$ \\
Free from inconveniences & 20 & $(1$ until 5) & $\mathrm{A}=\mathrm{B} \times \mathrm{C}$ \\
Free to behave naturally & 15 & $(1$ until 5) & $\mathrm{A}=\mathrm{B} \times \mathrm{C}$ \\
Free from fear and suffering & 15 & $(1$ until 5) & $\mathrm{A}=\mathrm{B} \times \mathrm{C}$ \\
\hline
\end{tabular}

Table 4. Classification of Bali Mynah welfare assessment

\begin{tabular}{lc}
\hline Classification assessment & Score \\
\hline Very Good & $80.00-100$ \\
Good & $70.00-79.99$ \\
Moderate & $60.00-69.99$ \\
Bad & $<60$ \\
\hline
\end{tabular}

\section{Release management of Bali Mynah}

Based on the data and information of Bali Barat National Park (BBNP) report (2012) and an interview with the manager of Breeding Centre of Bali Mynah (2015), the individual number of BM which had been released until 2012 was 218 birds. The individual number of BM released from 1998 to 2015 can be seen in Figure 1. BM release done by Tegal Bunder Breeding Centre of Bali Mynah consists of several stages, i.e. bird rearing in Tegal Bunder $\mathrm{BCBM}$, habituation in a habituation enclosure, bird release, post-release monitoring and release evaluation. BCBM has done the management activities of $\mathrm{BM}$ release in BBNP since 1998, but never evaluated. The BBNP has always only conducted techniques of bird release activities. Overall bird release management in BBNP has been carried out in accordance with the Standard Operating Procedure (SOP) of BM release made based on carrying capacity studies and BM release guidelines in BBNP (2013).

Bali Mynah rearing in Tegal Bunder BCBM is categorized as good, which is indicated by fulfilling the needs of food and water, the absent enemy, and the availability of nest boxes. BM release to the natural habitat still has deficiencies in the administration of the release event, namely in terms of the achievement.

\section{Bali Mynah maintenance in Tegal Bunder Breeding Centre Cages}

The BCBM in Tegal Bunder has 4 types of cage, namely breeding cage, weaning cage, quarantine cage, and release cage. The sizes of the cages are different depending 
on the function of the cages. The cages were made of iron frames and also had roofs. Cage accessories are enriched with perches made of wood branches with $2-2.5 \mathrm{~cm}$ diameter, planted grass, and woody plants.

The breeding cage size is $3 \mathrm{~m} \times 2.5 \mathrm{~m} \times 2.5 \mathrm{~m}$ that meets the requirement ( $4 \mathrm{~m} \times 4 \mathrm{~m} \times 2.5 \mathrm{~m}$ and $3 \mathrm{~m} \mathrm{x} 3 \mathrm{~m} \mathrm{x}$ $2.5 \mathrm{~m}$ ) for a couple of $\mathrm{BM}$ to breed. The important accessories in breed cages are the nest boxes. The availability of tree nest hole breeders is an important habitat component for BM living (Hernowo 2017). The extent of breeding cages influences the preparation and the success of the release (Mas'ud 2010). Weaning cage is in particular for rearing BM chicks. The size of this cage is 3 $\mathrm{m} \times 2.5 \mathrm{~m} \times 2.5 \mathrm{~m}$.

The size of the quarantine cages in Tegal Bunder Breeding Centre of Bali Mynah is $4 \mathrm{~m} \mathrm{x} 1 \mathrm{~m} \times 2.25 \mathrm{~m}$. Quarantine cages are made in a smaller size to limit the movement of sick birds so that they are easier to handle. The release cage has the largest size (10 m x $10 \mathrm{~m} \times 15 \mathrm{~m})$ compared to the other three types of cages. This is intended to make BM more easily adapt to their natural habitat. Tegal Bunder BCBM carries out the management and maintenance of the cages to ensure the cleanliness and comfort of the cage by having routine cage cleaning activities. This is done 2 times a week by cleaning the bird feces and the leftover feed that is on the cage floor.

Based on the results of field observations and referring to the statement above, the cages at Tegal Bunder BCBM are in appropriate condition and meet the needs of the BM. The maintenance of the cage is good, which makes BM in Tegal Bunder BCBM rarely stricken by diseases.

\section{Food and water}

The Bali Mynah is an insectivore and frugivorous bird. The daily portion of feed given in each breeding cage (a pair of birds) consists of 1 banana comb, 2 ounces of papaya, 5 crickets, 1 tablespoon of Hong Kong caterpillars (Tenebrio molitor), and 1 tablespoon of concentrate. For BM chicks, the portion of food provision will be added especially the type of Hong Kong caterpillar reaching 4 tablespoons, and this number depends on the number of tillers produced. Feed in the forms of Kroto caterpillars and crickets in Tegal Bunder BCBM is limited because the price is quite expensive. Feed is given routinely every day in the morning at 07.00-08.00 AM. The availability of water in captivity is considered supportive of the life of Bali starlings. Based on the results of field observations and referring to the explanation above, the provision of food and water for the BM that is routinely given in Tegal Bunder BCBM is good because it is sufficient to meet the needs of BM. According to Sudaryanto et al. (2015) the behavior of Bali Starling at Bali Barat National Park is for fruit feeding $3 \%$, insect feeding $1 \%$, and drinking $0,5 \%$, from the total of all the bird activities.

\section{Bird welfare}

Based on field observations, no BM in Tegal Bunder $\mathrm{BCBM}$ were found stricken by a disease. In terms of the breeding management of $\mathrm{BM}$, there are still deficiencies in the application of management of BM health, including the absence of clinics and laboratories that can support the management of BM. The bird care measures taken include cleaning up dirty bird body parts and bathing the bird using water spray. These activities are carried out every day, and bathing the bird is done at around 09.00 AM. The absence of medical experts at Tegal Bunder BCBM causes the examination of Bali starlings to only be done when the BM show symptoms of a disease. However, with the collaboration between BBNP and the Bali Mynah Breeder Association (APCB) since 2012, veterinarians from Bali Safari Park have been conducting routine inspections once a month. The development of BM population from January to May 2015 in Tegal Bunder BCBM can be seen in Figure 2.

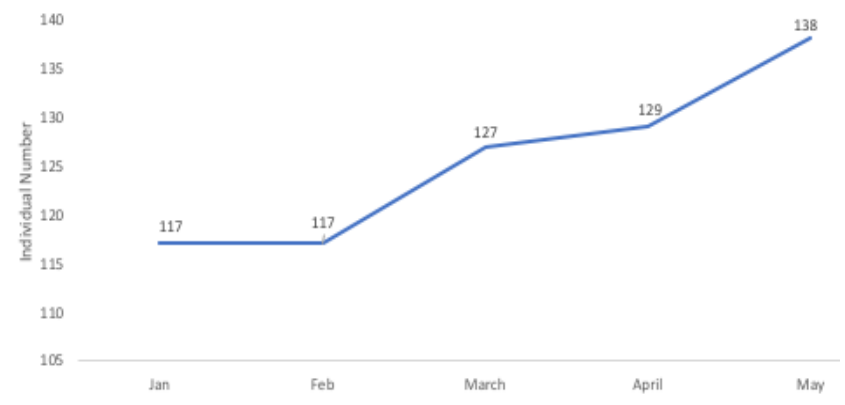

Figure 2. BM population development in Tegal Bunder BCBM January-May 2015

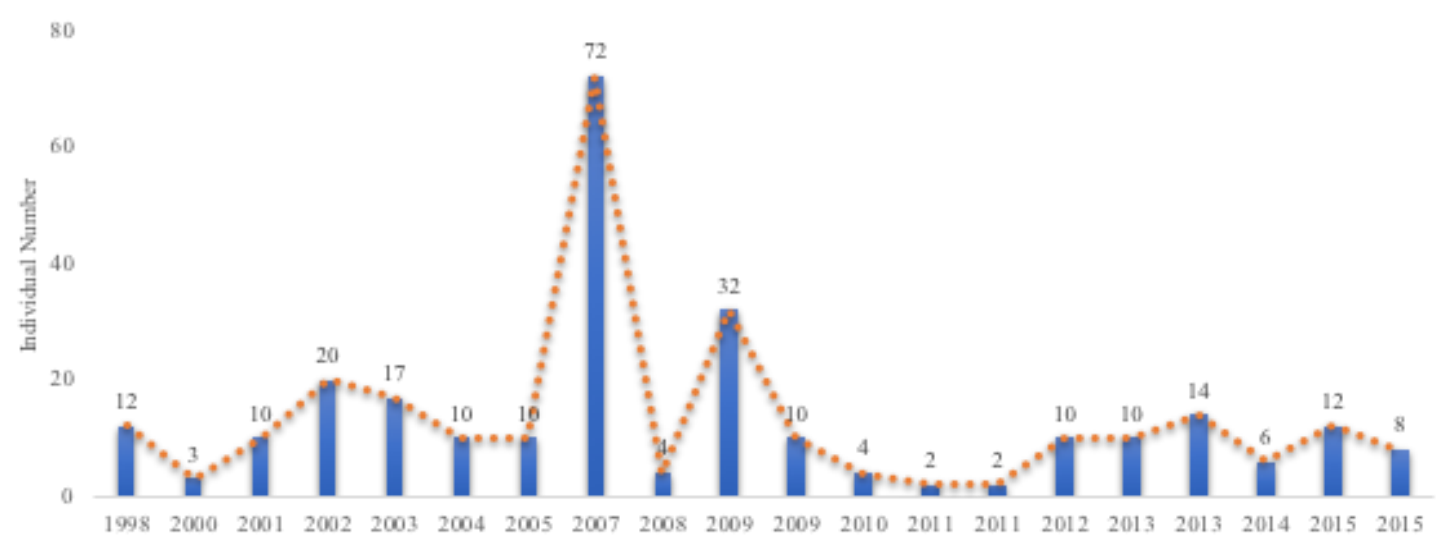

Figure 1. Individual number of BM released from 1998 to 2015 


\section{Bali Mynah population development}

Based on Figure 2, the breeding of BM in Tegal Bunder BCBM can be said as successful. This is indicated by an increase in the number of BM every month. This can support the BM release activities to the natural habitat with a population in captivity that continues to increase. Good breeding management of Tegal Bunder BCBM increases the number of $\mathrm{BM}$ populations that will increase the chances of release to their natural habitat. The BBNP cooperates with the community around Tegal Bunder BCBM to make community-based BM captive breeding that can support the release and provide the community with opportunities to utilize BM from captive breeding.

According to Earnhardt et al. (2009), the extinction risk assessment for the population of the Bali Mynah in captive, the projections indicate that under current management conditions, population decline and extinction are unlikely, and that although genetic diversity (GD) will decline over 100 years, the projected loss does not exceed levels acceptable to population managers (less than 90\% GD retained).

In order to better understand the reproductive activity of Bali starlings at the Durrell Wildlife Conservation Trust, Jersey, small cameras were placed inside the nest boxes of six pairs. Details of egg production and egg turning were recorded for 16 clutches, and incubation data were recorded for 14 clutches. Mean clutch size was $2 \cdot 820 \cdot 20$ SE eggs. Females incubated eggs significantly more than 77 (median 143.6 hours vs 46. 8 hours, 8 vs 7). During the day (0500-2100 hours) eggs were turned every c. 13 minutes (William and Feistner 2006).

\section{Bali Mynah individual selection for release}

Tegal Bunder BCBM carries out health examination on $\mathrm{BM}$ before the $\mathrm{BM}$ is released to prevent the spread of disease in nature. Based on observations, the average age of $\mathrm{BM}$ to be released to nature is 1-2 years old by having the criteria fulfilled balanced in Table 5. According to BBNP (2013), the age of BM ready to be released is around 1.5 years and ready for breeding as well as having a balanced sex ratio. Criteria for BM individual which have already been released can be seen in Table 5 .

According to Hernowo (2017), the attachment of rings on the BM is carried out to facilitate daily monitoring and find out the adaptation process of the $\mathrm{BM}$ in their natural habitat. However, during the release conducted at Pos Lampu Merah in December 2013, BM individuals were only given a colorless numbered ring, so it was difficult to monitor individual BM. Based on field observations and the previous explanation, the $\mathrm{BM}$ individual selection for release carried out by BBNP is appropriate.

\section{Management achievement assessment}

Based on observations, interviews, and assessments, the achievements of BM assessment management in Tegal Bunder BCBM have a good rating (Table 6).

The management assessment of BM in Tegal Bunder BCBM is included in the good category because the activities that have been done are good and appropriate. However, improvements in terms of implementation are still needed. Based on the results of the analysis, management assessment of the administrative components and management facilities get has the lower core of 4.18 because the data collection of BM, medical records, and statute books have not been regularly recorded. According to van Balen and Gepak (1994), in managing the many BM in captivity of BM, it is nice to make and update genealogical books to minimize the occurrence of inbreeding. This activities can help in the data collection of each individual of BM in Tegal Bunder BCBM which will be released. However, in this case, Tegal Bunder BCBM management is less updated in BM genealogical books. The human resource aspect also needs to be improved in terms of the availability of expert staff in the BBNP. The aspect of BM management also needs to be improved by adding the number of cages because the number of cages available is still lacking compared to the number of BM individuals. The constraint in Tegal Bunder BCBM is that there is no financial assistance for management and annual surveys that require large operational costs. This condition can be an obstacle in the efforts to improve breeding management in Tegal Bunder BCBM.

Table 6. Management assessment achievements of Bali Mynah

\begin{tabular}{lc}
\hline \multicolumn{1}{c}{ Component } & Score \\
\hline Administration and management facilities & 4.18 \\
Bird management & 4.50 \\
Bird welfare & 4.35 \\
Conservation and community empowerment & 4.33 \\
Human resources & 4.25 \\
Average & 4.32 \\
Predicate & Good \\
\hline
\end{tabular}

Table 5. Selective criteria for individual Bali Mynah which have already been released

\begin{tabular}{lll}
\hline Criteria & \multicolumn{1}{c}{ Remark } & \multicolumn{1}{c}{ Purpose } \\
\hline Age & $>1$ year & The effectiveness of the breeding process in nature \\
Individual origin & $\begin{array}{l}\text { Not from the same parent } \\
\text { The individual was declared by the Animal and Veterinary } \\
\text { Health }\end{array}$ & $\begin{array}{l}\text { Prevent inbreeding } \\
\text { Disease Investigation Center to be 'physically fit and not } \\
\text { handicapped' }\end{array}$ \\
Sex ratio & Male: Female ratio is $1: 1$ & \\
\hline
\end{tabular}


Table 7. Achievements in assessing the welfare of Bali Mynah in Tegal Bunder BCBM

\begin{tabular}{lccc}
\hline \multicolumn{1}{c}{ Component } & Weight & $\begin{array}{c}\text { Score } \\
\text { (average) }\end{array}$ & $\begin{array}{c}\text { Weight value } \\
\text { (weight x } \\
\text { score) }\end{array}$ \\
\hline Free from hunger and thirst & 30 & 4.13 & 123.9 \\
Free from pain, disease, injury & 20 & 4 & 80 \\
Free from inconveniences & 20 & 3.17 & 63.4 \\
Free to behave naturally & 15 & 3.55 & 53.25 \\
Free from fear and suffering & 15 & 4.14 & 62.1 \\
Total & & & 382.65 \\
Average & & & 76.53 \\
Value & & & Good \\
\hline
\end{tabular}

\section{Assessment of Bali Mynah welfare at Tegal Bunder BCBM}

Animal welfare can be measured by aspects related to being free from hunger and thirst, free from pain, injury and disease, free to display natural behavior, and free from fear and stress (Farm Animal Welfare Council 2001 in the Regulation of Directorate General of Forest Protection and Nature Conservation No. 6 (2011).

\section{Welfare assessment achievement}

Bali Mynah welfare assessment achievements at Tegal Bunder BCBM are classified in good categories. Based on the results of the assessment achievements analysis, several additions and improvements should be done. The aspect that should be improved is the addition of holes to some of the cages, the addition of vegetation in the cage, as well as the improvements in the health aspects that can be in the form of having additional medical facilities and recording the history of BM illness. Achievements in assessing the welfare of BM in Tegal Bunder BCBM can be seen in Table 7.

\section{The aspect of being free from hunger and thirst}

Feeding and drinking for BM can be classified as good and in accordance with the needs of BM. The thing to note in this aspect is the suitability of the portion in the feeding of BM. Feeding such as Hong Kong caterpillars (Tenebrio molitor) and insects need to be considered because it is a form of training for the BM to adapt to the natural habitat. The portion of the feed should encourage the wild behavior to strive and search for food even though they are in the cage.

\section{The aspects of being free from pain, illness, and injury}

Management of aspects includes the following: free from pain, disease, and injury for animal health conditions, frequency of health checks, animal health records, completeness and conditions of medical equipment facilities, types of drugs, conditions of storage of drugs, availability of medical experts, preparation for handling sick animals, and disease control and prevention. Health facilities in Tegal Bunder BCBM are inadequate, so if the BM suffers from severe pain, they will be handled immediately by medical experts from Bali Safari Park.

\section{The aspect of being free from environmental discomfort}

Free from discomfort can be realized by providing a place similar to the BM natural habitat. Existing facilities for the BM in the cage are in the form of perch tree trunks, nest boxes, and trees. Shade trees and cages are also covered by asbestos to protect them from bad weather. The completeness of the facility is an attempt to make the BM comfortable in terms of environmental factors. According to Riany and Aunurochim (2013), BM has a natural behavior that is sensitive to disturbances and easy to experience stress in environmental conditions that are not reasonable. This condition will affect the reproduction process.

\section{The aspect of being free to behave naturally}

Free to behave naturally provides opportunities for the $\mathrm{BM}$ in captivity with the right portion to choose and control their behavior. BM can select and determine their own behavior and their own quality of life. In the BM cage, it can be seen that the cage is enriched with perches and nest boxes, and the cover of the cage is made of asbestos to avoid any disturbance. The facility is intended for the BM to be free to express their natural behavior. Sudaryanto et al. (2015) mentioned that the behavior of Bali starling at Bali Barat National Park consists of flying 17\%, fruit feeding $3 \%$, insect feeding $1 \%$, preening $15 \%$, cresting head $6 \%$, bobbing $7 \%$, singing $40 \%$, drinking $0,5 \%$, and walking $10 \%$. In Nusa Penida the behavior during the rainy season consists of flying $13 \%$, fruit feeding $19 \%$, insect feeding $4 \%$, preening $7 \%$, cresting head $7 \%$, bobbing $8 \%$, singing $11 \%$, drinking $1 \%$, bathing $1 \%$, walking $16 \%$, nesting $2 \%$, brooding $9 \%$ and parental caring $3 \%$, while the behavior during the dry season consists of flying $11 \%$, fruit feeding $9 \%$, insect feeding $21 \%$, preening $7 \%$, cresting head $6 \%$, bobbing $7 \%$, singing $9 \%$, drinking $2 \%$, bathing $1 \%$, walking $18 \%$, and nesting $8 \%$.

\section{The aspect of being free from fear and depression}

Tegal Bunder BCBM has strived to make the Bali Mynah there free from fear and depression. This can be seen in BM nurses in Tegal Bunder BCBM who have had experience caring for BM for many years. Free from fear and distress includes freedom from fear and suffering caused by physical injury or intimidation from animals living in excessive social groups, external threats and illness, lack of animal management attention to stress and boredom, noise and noise problems, and smell and visual stimulation (Regulation of Directorate General of Forest Protection and Nature Conservation 2011).

\section{Pre-release stages \\ Preparation}

Prior to the release activities, the BM aged 10-12 months are moved from the weaning cage to the prerelease. The size of pre-release cages is $10 \mathrm{~m} \times 10 \mathrm{~m} \times 15$ $\mathrm{m}$. The cage size is larger than the other three cages, so that pre-release chicks are trained to fly high and become familiar with natural food. The level of dependence on feed provided by captive managers can be reduced. The BM that is aged 1.5-year-old are moved to habituation cages or 
release dome cage, which is located in release locations, and they stay there for $\pm 1-2$ months. This is the length of time it takes to practice their adaptability to their natural habitat conditions, reduce dependence on feeds given in captivity, provide natural food regularly, and monitor behavior and availability to search for natural food (BBNP 2013).

Bali Mynah release in BBNP is carried out through a soft release method. Each release site has different conditions. BM food needs in Tanjung Gelap are met naturally even though the manager does not feed them. At Pos Lampu Merah and Teluk Brumbun, the manager still provides BM food as a result of the release by gradually reducing the portion of feed. These three locations have different treatments because the availability of feed-in Tanjung Gelap is more than in Pos Lampu Merah and Teluk Brumbun. There is a river as a source of clean water in Tanjung Gelap, but there is no clean water available in Pos Lampu Merah and Teluk Brumbun, so it must be supplied from BBNP. Based on the field observations and analysis, the pre-release preparation activities in BBNP are already in accordance with the needs of the BM to be released in the wild. However, administrative activities in the field are still lacking because the recording data of daily activities and Bali Mynah range is not complete.

\section{The cage}

The BBNP has provided a number of supporting facilities for the success of the release of $\mathrm{BM}$ in their natural habitat, including the release dome (habituation cages and fastener cages) and the BM monitoring tower. Habituation cages in Teluk Brumbun, Tanjung Kotal and Tanjung Gelap are permanent habituation cages, while the ones in the Pos Lampu Merah are temporary habituation cages. The release dome cage is also used as a binding cage to lure BM which is released, so they do not fly far into residential or community agricultural land. The binding cage in Teluk Brumbun is used as a display cage for tourists who come to Teluk Brumbun. However, at the time of observation, individual $\mathrm{BM}$ as a binder did not exist in the release dome cage. Managers provide the BM with food every morning with smaller portions than in captivity. This reduction of feed is done to develop the wild instincts of $\mathrm{BM}$ to find alternative food in new environments (Sudaryanto et al. 2015). Based on the field observations and the analysis, the release dome cage is appropriate based on the characteristics of the permanent release dome cage. However, the management of the cage at the Teluk Brumbun location is inadequate, which can be seen from the condition of the untreated feed, pond, and not maintained enrichment.

\section{Release stages}

\section{Release administration}

One important thing in the effort to conserve BM through the BM release is the release report. The report should contain the number of BM submitted by Party I (BCBM Resort Head) to Party II (SPTN Resort Head), release locations, bird identity, and release time. The release report of BM in the BBNP needs a separate archive.
This is because the management in the archiving of release reports in BBNP has not been carried out properly, so several data about the BM release is hard to find or even absent.

\section{Release location}

Bali Mynah release locations were selected and determined by the BBNP from 1974 to 2015. The locations for the release are in Teluk Brumbun, Teluk Kotal, Tanjung Gelap, Pos Lampu Merah, Banyuwedang, Teluk Terima, Prapat Agung, Teluk Kelor and Cekik. Currently, only a few locations are used to release BM, namely Teluk Brumbun, Tanjung Gelap, Pos Lampu Merah and Cekik. Based on field observations and analysis, the location of the $\mathrm{BM}$ release in BBNP is suitable to meet the needs of BM. Released BM usually searches for food in mangrove forest, savanna, and monsoon forest because in these places it is easier to find food, especially insects. However, in Teluk Brumbun and the Pos Lampu Merah, the composition of habitats has changed into shrubs due to invasive species such as Kerasi (Lantana camara) and Kirinyuh (Cromolaena odorata).

\section{Release technique}

Bali Mynah release in BBNP uses two techniques namely hard release and soft release. The releases were carried out in 2007, 2009, and 2014 in Teluk Brumbun, Teluk Kotal and Tanjung Gelap. The hard release results in individuals having difficulties to adapt because the habituation to their new habitat is lacking and the level of adaptation to their natural habitat is low. The BM to be released using the soft release technique are placed in habituation cages for \pm 3 months so that the BM can adapt to their natural habitat. A high level of security is thought to be a success factor. At Tanjung Gelap, the BM population is released using the hard release technique. The $\mathrm{BM}$ which will be released by hard release $\mathrm{w}$ only put into the dome cage of release for 1-3 days, so the BM is not able to adapt well with their natural habitat, and as a result, several birds fly back to Tegal Bunder BCBM or to settlements around the release area.

Based on field observations, that BBNP uses a soft release technique shows that the released $\mathrm{BM}$ are able to become a productive population. The BM population has developed indicated by discovering an individual BM without a ring and with dull feather condition, which indicates that it is a bird whose parents are BM released previously. This condition is line with the expectation of Grand Design of Bali Starling in Bali Barat National Park (BBNP 2013). Hernowo (2017) mentioned that the BM release is needed since the existing population is very small or has sharply decreased to a critical condition. The Bali Mynah release is a historical monument for restocking and restoring the very small population in the wild habitat in Indonesia. The future release activities should comply with comprehensive studies about the habitat and the disturbance. According to Collins et al. (1998), many challenges remain for conserving this species, including poaching in the national park, disease in the captive 
population, predation by raptors on newly released birds, and destruction of essential habitat.

\section{Monitoring activities}

Monitoring activities are carried out around the release areas, which are around the Teluk Brumbun Resort, the Pos Lampu Merah and Tanjung Gelap. Monitoring activities are not carried out at Teluk Kotal because there have not been any individual BM released. Monitoring activities are carried out every morning at 06.00-07.00 WITA and in the afternoon at 17.00-18.00 WITA. Monitoring activities are carried out in conjunction with feeding and drinking BM activities. Monitoring of $\mathrm{BM}$ at each release location is done by counting the number of observed BM and recording the $\mathrm{BM}$ distribution.

Based on field observations, the BM monitoring carried out at the three locations for the BM release (Teluk Brumbun, Pos Lampu Merah and Tanjung Gelap) have been running effectively, but there are still shortcomings, namely the recording of daily activities of BM release that are not carried out regularly. Administrative activities in the field are still lacking, which can be seen from the field officers who only write the number of BM as a result of release. Monitoring activities are also complicated because color rings were not attached on BM legs, so officers only record the number of individuals found.

Hernowo (2017) reported that, in general, movement activities of BM after its release in 2007 is not far from feeding site, approximately $100-150 \mathrm{~m}$ away. The movement and local distribution are influenced by food given (ration) and man-made tree nest hole breeder distribution. In one case, it was found that one unmarked individual bird was observed moving at approximately 350 $\mathrm{m}$ away from the release cage. This condition indicated that the released BM was trying to move more than usual. Also, it provides information that the bird gradually moves to the wider surrounding areas. According to Hernowo (2017) observation, there was a case regarding bird movement, in which a BM bird released in 2009 at Brumbun united with a BM released at Tanjung Gelap ( $3 \mathrm{~km}$ away) formed a pair. This bird has a red color ring marked on its right feetwhite color ring marked on its left feet, and it was united with a bird marked white ring marked on its right feetgreen and red ring marked on its left feet. The movement of the birds has been observed only around their tree nest hole breeder at position ( $08^{\circ} 08^{\prime} 33.3^{\prime \prime} \mathrm{S}$ and $\left.114^{\circ} 33^{\prime} 05.3^{\prime \prime} \mathrm{E}\right)$.

\section{Evaluation of activities}

Evaluation is carried out through post-release monitoring activities. Since the beginning of the BM release in 1998, the evaluation of BM release activities in BBNP has never been carried out, so managers are still repeating the same things in terms of the way to conduct release activities. How the released BM can survive in the natural habitat has never been monitored or evaluated. Administrative activities in the field are also still lacking due to the not enough filing, so the data of BM release results are incomplete, resulting in a discrepancy in field data and reported data.

\section{Post-release stages}

Post-release monitoring on Bali Mynah release activities that have been done needs to be carried carry out to determine habitat use, distribution, activity, and productivity of the $\mathrm{BM}$ at the release site. According to Collins and Smith (1994), considerable research and care to $\mathrm{BM}$ are needed to ensure that the release program is productive and does not lead to increased poaching of wild birds. In particular, close monitoring of the birds after release is essential to determine the birds' movements and behavior and their effect on the existing population. Systematic observations reveal factors important to the released birds' success in the wild

\section{Population monitoring}

After \pm 3 months, released BMs were monitored for the population movements. The population movement ranges from $500 \mathrm{~m}^{2}$ to $1000 \mathrm{~m}^{2}$. The BM range is not far from the release dome cages. In general, the movement of the BM, after the release in 2007 monitored in 2010, is not far from feeding site, approximately $100-150 \mathrm{~m}$ away. The movement and local distribution are influenced by food given (ration) and distribution of man-made tree nest hole breeders (Hernowo 2017). The narrowness of BM range suggests that the BM population is still dependent on the availability of feed and nest boxes around the dome release cage. Individual number of BM released found based on every observation in release sites can be seen in Figure 3.

Based on the results of field observations, as many as 12-13 individual birds of released BM are found in Teluk Brumbun with more activities of searching for food and resting. In Teluk Brumbun, 3 productive pairs and 1 chick are found. The individual number of released BM found in Pos Lampu Merah is 16-21 individual birds, with 3 productive pairs and 6 chicks. At Tanjung Gelap, 1-3 individual birds are found. The individual number of BM populations released from the Pos Lampu Merah is the highest compared to Teluk Brumbun and Tanjung Gelap. Hernowo (2017) mentioned that in general, BM population development at Tanjung Gelap is in better condition (because the BM population increased from 2007 to 2009), with population development of approximately $10.53 \%$. There are many aspects affecting the success of BM release such as (i) bird conditions, (ii) released method (iii) management of released (iv) bird adaptability (v) disturbance. BM population development from 1974 to 2014 in BBNP can be seen in Figure 4.

In 2009, the number of BM populations released in Teluk Brumbun, Tanjung Gelap, and Teluk Kotal was among the highest total individuals compared to other years. However, in 2010 there was a significant decrease in the population of BM released. This was due to the release location which had been concentrated in Teluk Brumbun since 1998. According to Hernowo (2017), there are four factors related to the fluctuations in the condition of Bali Mynah populations as a result of release, namely the bioecological conditions of the BM, the state of the habitat condition, the state of community pressure, and the dedication of field officers. Concentration of release locations results in changes in the behavior of other 
animals, such as the gathering of animals at release sites due to the significant increase in the food ration of their released habitat when compared to other places (BBNP 2013).

This enrolled a wider range of stakeholders in the conservation of the species, including bird-keeping elites, and led to significant successes in restoring captive and free-flying populations (Jepson 2016). The BBNP is undertaking conservation efforts for the community-based Bali starling Sumber Klampok Village, which began in November 2010 to protect the BM population and prevent poaching. The BM with 15 pairs of brooders lent by the Bali Starling Conservation Association (APCB) in December 2012 and the Development of BM in Sumber Klampok Village can be said to be very good conditions. Until now there are 17 breeders who can produce as many as 30 birds.

\section{Nature adaptation}

The Bali Mynah population needs places to search for food, water, shelter, cover, and breeding places safe from disturbance. The BM population will live and develop naturally in suitable habitat. BM is an endemic bird to Bali and has naturally restricted distribution in west Bali. Habitat type of BM in BBNP is monsoon forest, savanna, beach forest and mangrove. The drought period in BBNP is 4-5 months, and the BM released will adapt to the condition. The pilang tree canopy is still green in dry season. BM also searches for food (fruit) of intaran tree
(Azadirachta indica). The tembelekan (Lantana camara) is an invasive species, but the fruit of this shrub species is one of food resources for BM. Savanna in Teluk Brumbun is dominated by kirinyuh (Chromolaena odorata), tembelekan shrubs, and alang-alang (Imperata cylindrica) grass. The management of savanna habitat in Teluk Brumbun should be considered to fulfill released BM needs. BM released used pilang tree, intaran tree, and tembelekan shrub as vegetation which is important for supporting habitat component of BM in BBNP. Availability of natural nest of BM is very limited. Nest boxes should fulfil the management of nest of BM. The number and distribution of nest boxes should be customized with the development of BM released. The Bali Mynah is mostly found at or near distinct vegetation boundaries, such as the border between savanna-forest; savanna-cropland; savanna-shrubland; settlement-cropland; and forest-shrubland (Sutomo and van Etten 2021).

The home range of Bali Mynah's couple in Nusa Penida is 3.9 ha. It consists of 2.3 ha agroforestry (59\%), 0.7 ha grasslands with coconut plantations (18\%), and settlement 0.9 ha (23\%). Activities of Bali Mynah (foraging, resting, and nesting) are mostly done in agroforestry area, which is $94 \%$ of the total area. Grassland is the main habitat of Black-winged starling (Acridotheres melanopterus) and Javan myna (Acridotheres javanicus) to forage insects on the body of cattle that graze there. Bali Mynah utilizes only $3 \%$ of this habitat. Bali Mynah also uses settlement area of as much as 3\% (Sudaryanto et al. 2020).

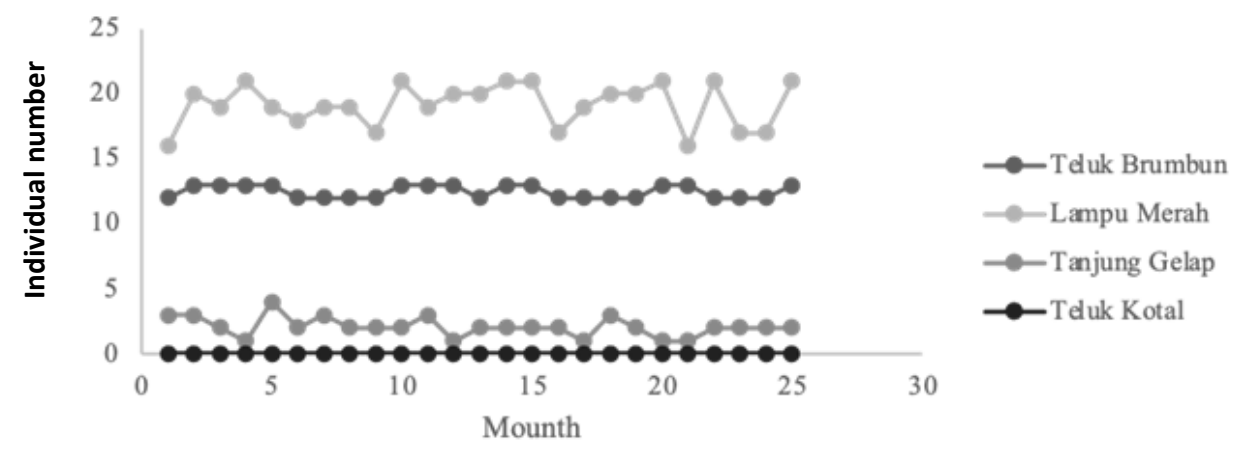

Figure 3. Individual number of released Bali Mynah found based on every observation in release sites

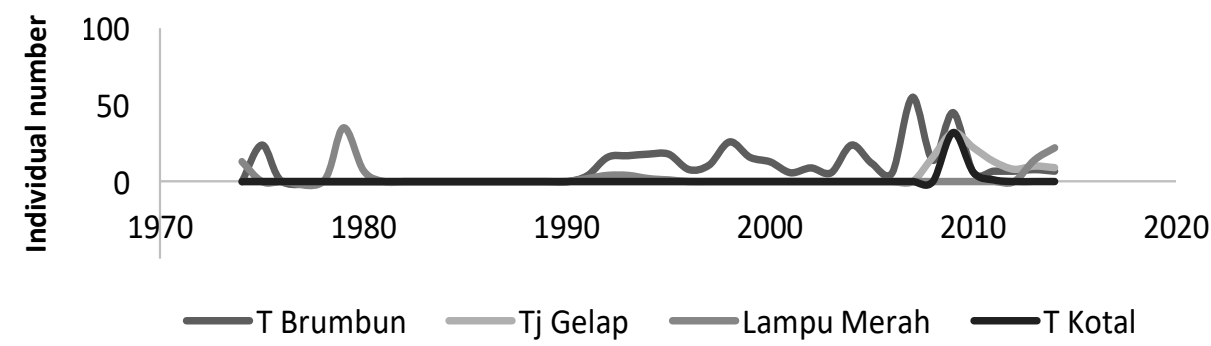

Figure 4. BM population development 1974-2014 in Bali Barat National Park, Indonesia 


\section{Habitat improvement}

Provision of feed tubs in Teluk Brumbun is done by placing feed at a height of 10 meters above the ground using pulleys, so that other animals do not eat Bali starling food. At the Pos Lampu Merah, the supply of the bird feed tubs is 2.5 meters above the ground, so monkeys can still disturb the BM feeding. Provision of the BM feed tubs in Tanjung Gelap is the same as the Pos Lampu Merah, but since February, the manager has not provided feed for BM. These conditions encourage BM in Tanjung Gelap to be able to find its natural food well. The installation of BM nest boxes is intended to be sufficient for the BM breeding place as a result of release. Teluk Brumbun provides 4-5 nest boxes for one pair of BM. This is done so that there are still other nest boxes as reserves if there are disturbances in one nest box. The Pos Lampu Merah and the Tanjung Gelap installation of nest boxes is adjusted according to the number of birds released. Invasive plant control in Teluk Brumbun, Post Lampu Merah Red is done by burning and clearing invasive plants. According to Hernowo (2017), the nest boxes should be evaluated for effectiveness. If the boxes are not used, they should be removed from strategic places. The distance between nest boxes should be more than that in the past if the birds do not depend on food rations. Extensive control of invasive plants in Teluk Brumbun is \pm 3 ha, and in the Pos Lampu Merah is \pm 1 ha, but it has never been carried out in Tanjung Gelap.

The Bali Mynah needs a habitat that can support adequacy of availability of food, water, nesting sites, resting sites, and protection from all threats. Habitat conditions of BM released at BBNP are dominated by pilang (Acacia leucophloea), tembelekan (Lantana camara), khirinyuh (Chromolaena odorata) and Imperata grasses (Imperata cylindrica). Dominated vegetation as food resources of $\mathrm{BM}$ released in Ped village of Nusa Penida is rather different with BBNP, juwet (Syzygium cumini), bekol (Ziziphus mauritiana), bunut (Ficus glabela), intaran (Azadirachta indica), ancak (Ficus rumphii), beringin (Ficus benjamina), tembelekan (Lantana camara), jambu biji (Psidium guajava) and jambu air (Psidium aquata) (Sudaryanto et al. 2020). According to Roemantyo (2011), the Bali Mynah mostly chooses pilang trees to perch, search for food, and rest. The $\mathrm{BM}$ released prefer pilang trees because the trees support resting site, provide food, and are hidden from predator attack.

Tree species that BM often uses as a source of food are pilangs and intaran. Pilang trees have potential as a source of food provide in the form of caterpillars and intaran trees as a source of food in the form of fruit. Savanna which is located in Teluk Brumbun has begun to be dominated by tembelekan (L. camara). The activity of savanna habitat improvement in Teluk Brumbun must be carried out immediately. The BM in Tanjung Gelap occupies monsoon forests dominated by pait woods as a source of food. At the Pos Lampu, the BM more often occupy pilang to get food. Sutomo and van Etten (2021) mentioned that there are several plant species used by Bali Mynah in the natural habitat in BBNP such as Ziziphus mauritiana, Grewia eriocarpa, Schleicera oleosa, Strepblus asper, Acacia leucophloea, and Lantana camara as food resources, while A. leucophloea and Borassus flabelifer are used by the birds as nesting sites.

The BM in Ped Village and Tambeling Forest Nusa Penida, use 29 vegetation species of shrubs and tree habitus. BM uses nest boxes and ancak (Ficus rumphii) and kapok randu (Ceiba petandra) as nesting sites, and coconut tree (Cocos nucifera) is a plant that Bali Mynah most often uses in all locations. On the other hand, the bunut tree (Ficus glabela) is the most beneficial species for the Bali Mynah as a place to perch, forage for food, and nesting sites (Riany and Aunurochim 2013). According to Hernowo (2017) in developing the BM habitat, the habitat must have sufficient components of feed, water, breeding site, shelter, and cover to avoid predators

Leucopsar rothschildi, Acridotheres tertius, and Acridotheres javanicus often use Ficus glabella for food, resting, and nesting in Nusa Penida, Bali (Sudaryanto et al. 2019).

\section{Safety from disturbance}

The success of the BM release is influenced by BM safety from poaching. The poaching activity has caused the BM population size to be very small in the BBNP (van Balen et al. 2000). Sutomo and van Etten (2021) also mentioned that poaching is a major threat to Bali Mynahs. This activity indicates the need to increase security around the release site. Besides poaching activities, the threat from fire has been warned by Pratama et al. (2017), saying that the habitat of Bali Mynah susceptibility to fire is high (2 $126006 \mathrm{ha})$. The BM security measure at the release locations that the BBNP has carried out is in the form of an increase in the intensity of guard or routine patrols by the Forestry especially in the BM release sites. However, the poaching that occurred in Teluk Kotal caused the location to no longer be used as a release site due to a lack of security. Besides hunting and trade, deforestation and habitat destruction are the most dominant factors in the reduction of the number of bird species and their possible extinction (Ayat and Tata 2015). The predators and competitors of $\mathrm{BM}$ at released sites can be seen in Table 8 . According to BBNP (2012), the carcass of BM found in the field indicates that predators attacked the bird.

Birds species as a potential competitor to BM in terms of food resources (insect) is Yellow Vented Bulbul (Pycnonotus goiavier) with a domination $=11.91 \%$. Domination of yellow vented bulbul is in high category and their distribution is evenly spread in Tanjung Gelap and Prapat Agung (Widodo 2014). Bird species as potential competitors to $\mathrm{BM}$ in terms of nesting site are White Collared kingfisher (Halcyon chloris), Lineated Barbet (Megalaima lineata), Coopersmith barbet (Megalaima haemacephala) (Widodo 2014). According to Sudaryanto et al. (2020), in Nusa Penida, the competition between Bali Mynah, Black-winged Starling and Javan Myna, is especially very often to obtain food sources and nesting sites, for example, every morning for sucking nectar. 
Table 8. The predator and competitor of Bali Mynah at released site

\begin{tabular}{lll}
\hline Release site & \multicolumn{1}{c}{ Predator } & \multicolumn{1}{c}{ Competitor } \\
\hline Teluk & $\begin{array}{l}\text { Eagle, Civet, Water } \\
\text { monitor, Hawk, } \\
\text { Srumbun }\end{array}$ & $\begin{array}{l}\text { Yellow Vented Bulbul, } \\
\text { Long Tailed Macaque, } \\
\text { Squirrel, Rat, Gecko, Bee, } \\
\text { Black Wing Starling }\end{array}$ \\
Pos Lampu & $\begin{array}{l}\text { Eagle, Snake, } \\
\text { Kerah }\end{array}$ & $\begin{array}{l}\text { Civet, Water } \\
\text { monitor, Monkey, Yellow Vented }\end{array}$ \\
& Wulbul \\
Wanjung & Water monitor, & Kingfisher, Yellow \\
Gelap & Eagle, Snake, Civet & Vented Bulbul, Barbet \\
\hline
\end{tabular}

Aggressive behavior often occurs in the breeding season. This was observed in Pura Dalem Bungkut, when Bali Mynah fought with Black-winged starling competing for a nesting site, which was won by Bali Mynah. Bali Mynah also often competes with Green-imperial pigeon (Ducula aenea), Sooty-headed bulbul (Pycnonotus aurigaster), and Black-naped oriole (Oriolus chinensis) for food. Fighting to compete for water vessels dedicated to drinking and bathing occurs between Bali Mynah with Sooty-headed bulbul and Spotted dove (Speliopelia chinensis). The predator of Bali Mynah is Monitor lizard (Varanus salvator). Monitor lizard preys on eggs and tillers that are in the nest. During field observation, observers found a young Bali Mynah preyed by Monitor lizard in Biaung Village. Symbiotic mutualism occurs between Bali Mynah and Bali cattle (Bos javanicus). In groups or individually, Bali Mynah look for insects in the body of Bali cattle that are grazing in pastures in coconut plantations. Black-winged starling and Javan myna are the main inhabitants of this prairie habitat, so there is a competition between these species with the Bali Mynah (Sudaryanto et al. 2020).

\section{Survival in nature}

Development population of BM released in BBNP can be seen in Figure 5. Based on Figure 5, the survival ability of released $\mathrm{BM}$ populations has fluctuated in nature. According to Hernowo (2017), future release activities of BM should be accompanied by comprehensive studies in relation to the habitat and the disturbance. The adequate habitat availability can result in a limited distribution of $\mathrm{BM}$ released and affect the ability to survive and reproduce of the released birds. The habitat quality in all release sites (Tanjung Gelap, Teluk Brumbun, Pos Lampu Merah) need to be improved. Besides improving the habitat quality, several management activities should be done continuously in terms of bird safety. In 2013, the Pos Lampu Merah showed an increase in population of BM released to nature. According to Bird Recovery International (2011), the success of release programs can be seen in whether the birds are in good condition during the preparation of the release and how the birds can survive in nature. In general, birds use the habitats for food sources, water sources, shelter, and cover (Kurnia et al. 2021).

\section{BM juvenile bird development}

The development of BM population released from 1997 to 2012 shows that the number of chicks (juvenile bird) increased in Teluk Brumbun and Pos Lampu Merah (Figure $6)$.

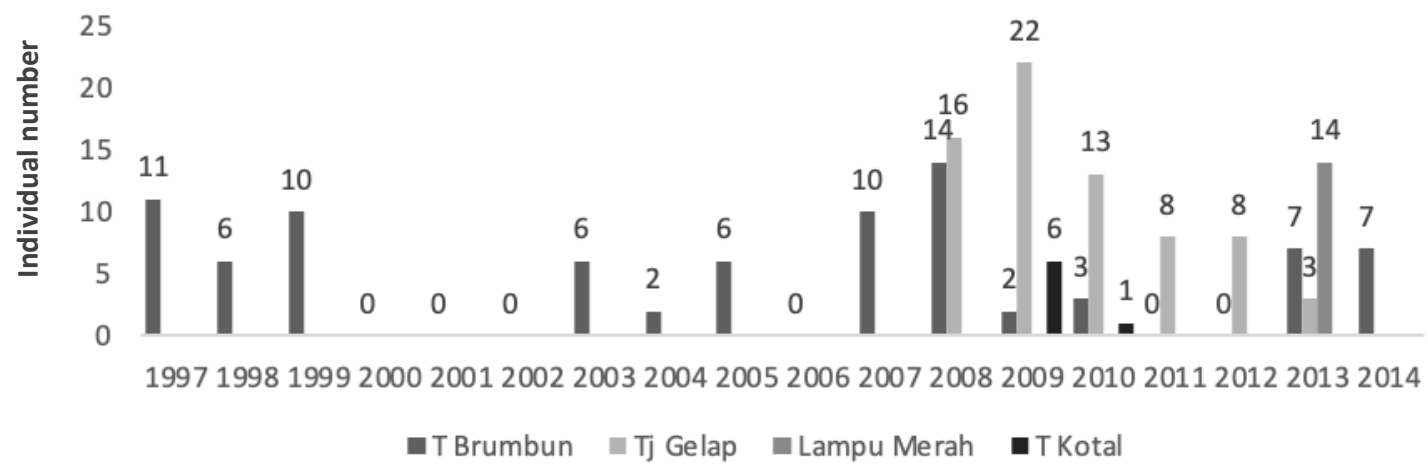

Figure 5. The survival of BM population in release sites

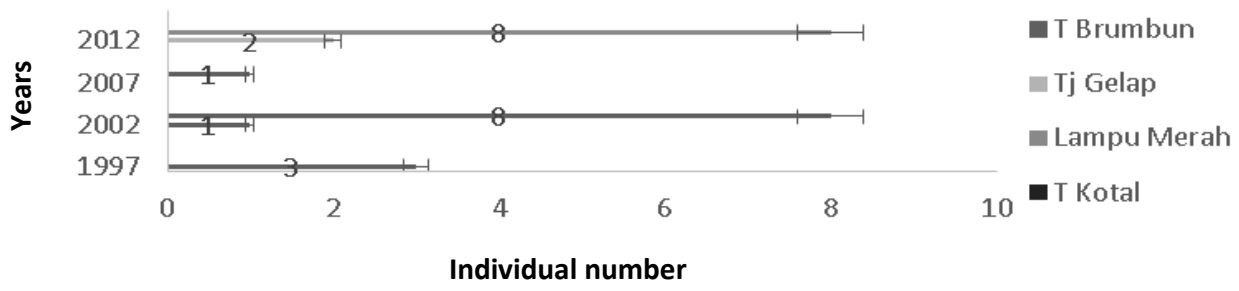

Figure 6. Total of BM released chicks in release sites 
Teluk Brumbun in 2002 and Pos Lampu Merah in 2012 showed the highest total number of BM produced by 8 juvenile bird (Figure 6). The released BM population is included in a very small population, and we consider the possibility of not being able to avoid the occurrence of inbreeding. Besides natural disasters, such as a long drought, fire and disease outbreaks can easily make the small population extinct (Balen et al. 2000). Based on field observations, there were 3 active pairs of BM released in the Pos Lampu Merah. This shows that the habitat at the Pos Lampu Merah can support the life of released BM. Population analysis of BM released in 2007 shows that released BM population in Tanjung Gelap has increased (Hernowo 2017).

In conclusion, (i) Tegal Bunder BCBM in terms of the management of $\mathrm{BM}$ release with welfare assessment criteria is classified as good with the value of each criterion being 76.53 and 4.32 , (ii) The BM release process in Teluk Brumbun, Teluk Kotal, Tanjung Gelap and Pos Lampu Merah is classified as good, and the success of birds living in the wild determined by the bio-ecological conditions of the BM, the condition of the BM habitat (availability of food, water, shelter, nesting sites), and bird safety from disturbance should certainly support BM living. Management techniques at each release site are good, but the low level of security and administrative activities in the field are still lacking, (iii) The development of released BM populations is fluctuating, but generally leads to an increase, (iv) BM population security is one of the main factors in release management that needs to be considered to ensure the sustainability of BM in the field. Bird safety must be improved.

\section{REFERENCES}

Ayat A, Tata HL. 2015. Diversity of birds across land use and habitat gradients in forests, rubber agroforests and rubber plantations of North Sumatra, Indonesia. J For Res 2(2): 103-120. DOI: 10.20886/ijfr.2015.2.2.103-120.

BirdLife International 2018. Leucopsar rothschildi. The IUCN Red List of Threatened Species 2018: e.T22710912A129874226. DOI: 10.2305/IUCN.UK.20182.RLTS.T22710912A129874226.en.

BBNP. 2012. Evaluation report Bali Starling In Area of Bali Barat National Park. Bali Barat National Park, Bali. [Indonesian]

BBNP. 2013. Grand Design of Bali Starling In Bali Barat National Park 2013-2017. Bali Barat National Park, Bali. [Indonesian]

Bird Recovery International. 2011. Offering hope for birds facing extinction. Moab UT (206) 618-2610.

Collins MS, Smith TB. 1994. Post-release behavior and movements of the Bali Mynah (Leucopsar rothschildi). In: AFA Watchbird (ed.s). AFA Species Survival Plan, USA.

Collins MS, Smith TB, Seibels RE, Putra IMWA. 1998. Approaches to the reintroduction of the Bali Mynah. Zoo Biol 17(4): 267-284. DOI: 10.1002/(SICI)1098-2361(1998)17:4<267::AID-ZOO2>3.0.CO;2-7.
Convention on International Trade in Endangered Species of Wild Fauna and Flora (CITES). 2019. Appendices I, II and III. https://cites.org/eng/app/appendices.ph

Earnhardt JM, Thompson SD, Faust IJ. 2009. Extinction risk assessment for the species survival plan (SSP) population of Bali Mynah (Leucopsar rothschildi). Zoo Biol 28 (3): 230-252. DOI: 10.1002/zoo.20228

Hernowo JB. 2017. Population analysis of Bali Mynah (Leucopsar rothschildi Stresemann, 1912) release in 2007 in Bali Barat National Park, Indonesia. Trop Drylands 1 (2): 83-89. DOI: 10.13057/tropdrylands/t010204.

Kurnia I, Harnios A, Mardiastuti A, Hermwan R. 2021. The potential of bird diversity in the urban landscape for birdwatching in Java, Indonesia. Biodiversitas 22 (4): 1701-1711. DOI: $0.13057 /$ biodiv/d220413.

Jepson PR. 2016. Saving a species threatened by trade: A network study of Bali starling Leucopsar rothschildi conservation. Oryx 50(3): 480488. DOI: 10.1017/S0030605314001148.

Mas'ud B. 2010. Teknik Menangkarkan Burung Jalak di Rumah. IPB Press, Bogor. [Indonesian]

Pratama F, Prsetyo LB, Rushayati SB. 2017. The habitat susceptibility of Bali starling (Leucopsa rothschildi Stresemann 1912) based on forest fire vulnerability mappin in West Bali National Park. IOP Conf Ser: Earth Environ Sci 91 (1): 012003. DOI: 10.1088/17551315/91/1/012003.

Peraturan Direktur Jenderal Perlindungan Hutan dan Konservasi Alam (per dirjen PHKA) Nomor P.6/IV-SET/2011 Tentang Pedoman Penilaian Lembaga Konservasi. [Indonesian]

Riany CF, Aunurochim 2013. Bali starling (Leucopsar rothschildi) population result from release in Ped village and Tambeling Forest of Nusa Penida Island, Bali. Jurnal Sains and Seni Pomit 2 (2): 23373520. [Indonesian]

Roemantyo. 2011. Vegetation structure and composition of monsoon forest as habitat of Bali starling (Leucopsar rothschildi Stresemann, 1912) in Labuan Lalang, West Bali National Park. J Biol Indon 7 (2): 361-374. [Indonesian]

Sudaryanto, Djohan TS, Pudyatmoko S, Subagja J. 2015. Behavior of Bali starling at Bali Barat National Park and Nusa Penida Island. Jurnal Veteriner 16 (3): 364-370. [Indonesian]

Sudaryanto FX, Hardini J, Kalih LATTWS, Asrori MM, Suwana IW. 2019. Bird communities and vegetation composition in Nusa Penida, Bali, Indonesia. Biodiversitas 20: 3676-3683. DOI: 10.13057/biodiv/d201229.

Sudaryanto FX, Pudyatmoko S, Djohan TS, Subagja J, Suwana IW, Kalih LATTWS, Hardini J, Subagio J. 2020. Daily activity, diet and habitat of Bali Mynah (Leucopsar rothschildi) in Nusa Penida, Bali, Indonesia. Biodiversitas 21 (10): 4474-4482. DOI: 10.13057/biodiv/d211002.

Sutomo, van Etten E. 2021. Bali starling (Leucopsar rothschildi) natural habitat in Bali Barat National Park, Indonesia. Biotropia. DOI: 10.11598/btb.0.0.0.1174.

van Balen S, Gepak VH. 1994. The captive breeding and conservation programme of Bali starling Leucopsar rothchildi. In: Olney PJS, Mace GM, Felstner ATC (eds). Interactive Management of Wild and Captive Animals. Creative Conservation. Chapman \& Hall, London, UK. DOI: 10.1007/978-94-011-0721-1_24.

van Balen B, Dirgayusa IWA, Putra IMWA, Prins HH. 2000. Status and distribution of the endemic Bali starling Leucopsar rothschildi. Oryx 34(3): 188-197. DOI: 10.1017/S0030605300031185.

Widodo W. 2014. Composition and important value index of birds in relation to study of Bali starling (Leucopsar rothschildi) In the Bali Barat National Park. Zoo Indonesia 23: 21-34. [Indonesian]

Williams TM, Feistner ATC. 2006. Reproduction of Bali starlings Leucopsar rothschildi at Durrell Wildlife Conservation Trust, Jersey. Intl Zoo Yearb 40: 271-289. DOI: 10.1111/j.1748-1090.2006.00271.x. 